\title{
Kejelasan Sasaran Anggaran, Sistem Pelaporan dan Kompetensi Perangkat Desa pada Akuntabilitas Pengelolaan Dana Desa
}

\author{
Putu Ika Sawitri ${ }^{1}$ \\ Fakultas Ekonomi dan Bisnis \\ Universitas Udayana, Indonesia
}

\author{
Gayatri ${ }^{2}$ \\ Fakultas Ekonomi dan Bisnis \\ Universitas Udayana, Indonesia
}

\begin{abstract}
Surel : ikasawitri@gmail.com
\section{ABSTRAK}

Tujuan dari penelitian ini adalah untuk mengetahui pengaruh kejelasan sasaran anggaran, sistem pelaporan dan kompetensi perangkat desa pada akuntabilitas pengelolaan dana desa. Akuntabilitas pengelolaan dana desa merupakan mekanisme pertanggungjawaban pemerintah desa kepada masyarakat dan pemerintah pusat dalam pengelolaan dana desa. Penelitian ini dilakukan di seluruh desa di wilayah Kota Denpasar. Jumlah desa yang digunakan dalam penelitian ini sebanyak 27 desa dan jumlah sampel dalam penelitian ini 135 orang dengan metode purposive sampling, responden yang dipilih merupakan perangkat desa yang terlibat dalam pengelolaan dana desa. Pengumpulan data dilakukan dengan menggunakan kuesioner. Teknik analisis yang digunakan adalah regresi linear berganda. Berdasarkan hasil penelitian menunjukan bahwa kejelasan sasaran anggaran, sistem pelaporan dan kompetensi perangkat desa berpengaruh positif dan signifikan pada akuntabilitas pengelolaan dana desa.
\end{abstract}

Kata Kunci: Anggaran; Pelaporan; Kompetensi; Akuntabilitas.

\section{Clarity Budget Objectives, Reporting Systems, And Competency in Accountability of Village Fund Management}

\section{ABSTRACT}

The purpose of this study was to determine the effect of clarity on budget targets, reporting systems and the competence in accountability of village fund management. This research was conducted on 27 villages in Denpasar City. Respondents in this study was 135 people with a purposive sampling method. Data collection was carried out using a questionnaire. The analysis technique used is multiple linear regression. Based on the research results, it shows that the clarity of budget targets, the reporting system and the competence of village officials have a positive and significant effect on the accountability of village fund management.

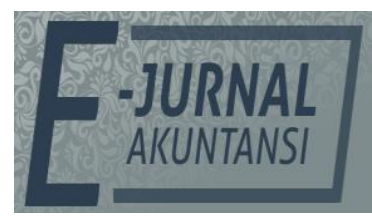

e-ISSN 2302-8556

Vol. 31 No. 2

Denpasar, Februari 2021

Hal. 476-489

DOI:

10.24843/EJA.2021.v31.i02.p17

PENGUTIPAN:

Sawitri, P.I., \& Gayatri. (2021). Kejelasan Sasaran Anggaran, Sistem Pelaporan dan Kompetensi Perangkat Desa pada Akuntabilitas Pengelolaan Dana Desa. EJurnal Akuntansi, 31(2), 476-

RIWAYAT ARTIKEL: Artikel Masuk: 19 Agustus 2020 Artikel Diterima: 19 Februari 2021

Keywords: Budget; Reporting; Competence; Accountability.

Artikel dapat diakses : https://ojs.unud.ac.id/index.php/Akuntansi/index 


\section{PENDAHULUAN}

Undang-Undang No 6 Tahun 2014 tentang desa memberikan kesempatan yang lebih besar bagi desa untuk mengurus tata pemerintahannya sendiri serta pemerataan pelaksanaan pembangunan untuk meningkatkan kesejateraan dan kualitas hidup masyarakat desa. Tujuan dari adanya dana desa yaitu untuk meningkatkan pelayanan publik di desa, mengentaskan kemiskinan, memajukan perekonomian desa, mengatasi kesenjangan pembangunan antardesa, dan memperkuat masyarakat desa sebagai subjek pembangunan. Melalui dana desa, program dari pemerintah dapat lebih cepat tersampaikan kepada masyarakat sehingga tercapainya desa yang maju, kuat dan mandiri. Mewujudkan akuntabilitas dan menumbuhkan kepercayaan publik terhadap kinerja keuangan pemerintah merupakan hal terpenting dalam mengelola keuangan pemerintah. Akuntabilitas dalam pengelolaan dana desa yang dilakukan oleh perangkat desa merupakan kewajiban perangkat desa dalam upaya mengurangi peluang korupsi, memperkuat mekanisme pemantauan internal dan eksternal serta sebagai bukti penerapan tata kelola pemerintahan yang baik (Fitriyani et al., 2018). Penerimaan dana desa Provinsi Bali pada tahun 2019 sebesar Rp 630 miliar yang di transfer ke 9 kabupaten dan kota di provinsi. Pada tahun 2019 Kota Denpasar menerima dana desa sebesar Rp 34.750.461.000 dan telah dialokasikan ke 27 desa yang terdapat di empat kecamatan yang ada di Kota Denpasar (BPKP, 2019). Prioritas penggunaan dana desa dialokasikan untuk tujuan pembangunan desa, meningkatkan kesejahteraan desa dan penanggulangan kemiskinan (Adhayanto et al., 2019). Alokasi dana desa yang memiliki jumlah yang besar memiliki konsekuensi terjadinya kecurangan yang dapat dilakukan oleh pihakpihak tertentu yang memiliki kewenangan dalam mengelola dana desa. Menurut Indonesia Corruption Watch (ICW) ada empat faktor yang menyebabkan terjadinya korupsi dana desa yaitu: pertama; kurang melibatkan masyarakat dalam proses perencanaan dan pengawasan dana desa; kedua; terbatasnya kompetensi kepala desa dan perangkat desa; ketiga; tidak optimalnya lembaga desa; keempat; biaya politik yang tinggi akibat kompetitifnya arena pemilihan kepala desa. Terdapat beberapa hambatan dalam penyaluran dan penggunaan dana desa, seperti rendahnya kapabilitas dan kapasitas sumber daya manusia dalam pemerintahan desa (Azlina et al., 2017). Keaktifan partisipasi masyarakat desa yang masih sangat minim dapat menimbulkan kecurangan-kecurangan dalam mengelola keuangan desa (Aziz, 2016).

Akuntabilitas merupakan salah satu prinsip tata kelola pemerintahan yang baik yang memiliki arti penting untuk meningkatkan kepercayaan masyarakat atas aktivitas atau program yang dirancang dan dijalankan oleh pemerintah untuk kepentingan publik (Azziiz \& Prastiti, 2019). Dalam suatu pemerintahan desa, kejelasan sasaran anggaran akan berdampak pada pemaksimalan penggunaan dana yang kemudian aparatur desa akan memiliki informasi yang cukup untuk memprediksi masa depan secara tepat. Ketidakjelasan sasaran anggaran akan menyebabkan aparatur mengalami kesulitan dalam penyusunan target-target anggaran (Panjaitan \& Shopiana, 2017). Penelitian yang dilakukan oleh Efrizar et al, (2017) menunjukkan kejelasan sasaran anggaran berpengaruh positif terhadap akuntabilitas kinerja instansi. Demikian juga penelitian yang dilakukan oleh Amalia (2017) menunjukkan hasil 
bahwa kejelasan sasaran anggaran berpengaruh positif dengan akuntabilitas kinerja pemerintah daerah. Penelitian yang dilakukan oleh Afrida (2017) menunjukkan hasil yang berbeda bahwa kejelasan sasaran anggaran berpengaruh negatif terhadap akuntabilitas kinerja pemerintah daerah.

Sistem pelaporan yang baik diperlukan agar dapat memantau dan mengendalikan kinerja manajer dalam mengimplementasikan anggaran yang telah ditetapkan (Afiah \& Azwari, 2015). Laporan yang baik adalah laporan yang harus disusun dengan jujur, objektif dan transparan. Pemerintah desa selaku pengelola dana desa harus mampu menyediakan informasi keuangan yang diperlukan secara akurat, relevan, tepat waktu, konsisten, dapat dipercaya serta akses yang mudah bagi masyarakat untuk mengakses infomasi keuangan (Triyono et al., 2019). Penelitian yang dilakukan oleh Hidayattullah \& Herdjiono (2015) menyimpulkan bahwa sistem pelaporan berpengaruh pada akuntabilitas kinerja pemerintah. Hal yang sama juga di simpulkan oleh Efrizar et al., (2017) yang menyatakan sistem pelaporan berpengaruh positif pada akuntabilitas publik. Hasil yang berbeda dinyatakan oleh penelitian yang dilakukan oleh Precelina \& Wuryani (2019) menyatakan sistem pelaporan tidak berpengaruh pada akuntabilitas kinerja pemerintah daerah. Pemerintah desa dalam melakukan pengelolaan dana desa dituntut untuk melaksakan tugas secara akuntabel dan transparan agar tidak terjadi tindakan penyelewengan (Aulia et al., 2018).

Penyelewengan dana desa dapat terjadi karena kurangnya akuntabilitas dalam penggunaan dana desa serta kurangnya kompetensi perangkat desa (Ashshidiqqi \& Wibisono, 2018). Kualitas perangkat desa yang baik sangat dibutuhkan dalam melaksanakan tugas dan untuk mewujudkan akuntabilitas dalam pengelolaan keuangan desa (Meutia \& Liliana, 2018). Ada tiga kompenen utama dalam membentuk sumber daya manusia yaitu pengetahuan, kompetensi dan perilaku (Dewi et al., 2019). Dalam pengelolaan keuangan yang baik, perangkat desa harus memiliki sumber daya manusia yang berkualitas, didukung dengan latar belakang pendidikan dan pelatihan, serta dengan mempunyai pengalaman dibidang keuangan sehingga sumber daya manusia tersebut mampu memahami logika akuntansi dengan baik dalam penerapan sistem akuntansi. Penelitian yang dilakukan oleh (Atmadja et al., 2018) menyatakan kompetensi perangkat desa berpengaruh signifikan pada pengelolaan dana desa. Penelitian yang dilakukan oleh Santoso (2016) begitupula penelitian yang dilakukan oleh Setyanto \& Ritchi (2018) menyimpulkan bahwa sumber daya manusia berpengaruh signifikan terhadap akuntabilitas keuangan daerah. Namun berbeda dengan hasil penelitian yang dilakukan oleh Prasetya et al., (2017) yang menyimpulkan bahwa kompetensi sumber daya berpengaruh negatif terhadap kualitas penerapan SISKEUDES yang merupakan pertanggungjawaban pengelolaan dana desa.

Laporan pengawasan semester II yang dilakukan oleh Badan Pengawasan Keuangan dan Pembangunan Provinsi Bali, menyatakan terdapat banyak masalah dalam pengelolaan dana desa di Kota Denpasar. Permasalahan yang terjadi yaitu pada penatausahaan pengelolaan keuangan desa yang masih terdapat kesalahan dalam implementasi aplikasi siskeudes, kesalahan penganggaran dalam APBDes, BUMDes yang belum menetapkan anggaran 
dasar dan anggaran rumah tangga serta belum dilakukan pencatatan aset atas pekerjaan yang sudah selesai (BPKP, 2018).

Fenomena tersebut melatarbelakangi peneliti untuk melakukan penelitian mengenai pengaruh kejelasan sasaran anggaran, sistem pelaporan dan kompetensi perangkat desa pada akuntabilitas pengelolaan dana desa di Kota Denpasar. Penelitian ini bertujuan untuk memperoleh bukti empiris mengenai pengaruh kejelasan sasaran anggaran, sistem pelaporan dan kompetensi perangkat desa pada akuntabilitas pengelolaan dana desa. Secara praktis penelitian berguna sebagai bahan masukan bagi pemerintah desa se-Kota Denpasar dalam mewujudkan akuntabilitas pengelolaan dana desa.

Teori keagenan merupakan konsep yang menjelaskan hubungan kontraktual antara prinsipal dan agen. Prinsip utama teori ini berupa hubungan kerja antara pihak yang memberi wewenang (prinsipal) dengan pihak lain yang menerima wewenang (agensi) dalam bentuk kontrak hubungan kerja sama. Pendelegasian wewenang terjadi ketika seseorang atau satu kelompok orang (prinsipal) memilih orang lain atau kelompok lain (agen) untuk bertindak sesuai dengan kepentingan principal (Boučková, 2015). Hubungan prinsipal dan agen merupakan suatu pendekatan yang yang sangat penting untuk menganalisis komitmen-komitmen kebijakan publik. Pembuatan dan penerapan kebijakan publik berkaitan dengan masalah-masalah kotraktual, yakni informasi yang tidak simetris (asymmetric information) (Glinkowska \& Kaczmarek, 2016). Akuntabilitas dapat terwujud apabila terdapat komitmen dari pempinan dan seluruh staf instansi pemerintahan yang bersangkutan untuk menjamin penggunaan sumber daya secara konsisten sesuai dengan peraturan perundangundangan (Santoso, 2016). Dengan kata lain, kepala desa dan aparaturnya harus mempertanggungjawabkan pengelolaan sumber daya serta pelaksanaan kebijakan yang dipercayakan kepada entitas pelaporan dalam mencapai tujuan yang telah ditetapkan secara periodik. Transparansi memberikan informasi keuangan yang terbuka dan jujur kepada masyarakat berdasarkan pertimbangan bahwa masyarakat memiliki hak untuk mengetahui secara terbuka dan menyeluruh atas pertanggungjawaban pemerintah dalam pengelolaan sumber daya yang dipercayakan kepadanya dan ketaatan pada peraturan perundangundangan.

Kejelasan sasaran anggaran mengacu pada sejauh mana tujuan anggaran tersebut dinyatakan secara spesifik, jelas dan bisa dimengerti oleh pihak yang bertanggungjawab terhadap pencapaiannya. Teori agensi menjelaskan bahwa akuntabilitas merupakan bentuk pertanggungjawaban kinerja atas dana yang diperoleh dengan demikian kejelasan sasaran sangat dibutuhkan untuk mencapai tujuan. Penelitian yang dilakukan oleh Amalia (2017) dan Ruri (2016) menyimpulkan bahwa kejelasan sasaran anggaran berpengaruh positif pada akuntabilitas kinerja Pemerintah. Penelitian ini sejalan dengan penelitian yang dilakukan oleh Arta \& Rasmini (2019) menyimpulkan bahwa kejelasan sasaran anggaran berpengaruh positif pada akuntabilitas.

$\mathrm{H}_{1}$ : Kejelasan sasaran anggaran berpengaruh positif pada akuntabilitas pengelolaan dana desa di Kota Denpasar.

Pengelolaan keuangan desa mewajibkan orang-orang yang terlibat dalam pemgelolaan keuangan melakukan pelaporan untuk mewujudkan pengelolaan 
keuangan yang transparan dan akuntabel. Teori agensi menjelaskan tentang pentingnya sistem pelaporan dalam menjaga kepercayaan yang diberikan oleh pemerintah pusat dan masyarakat kepada pemerintah desa dalam mengelola keuangan desa. Sistem pelaporan dalam sektor publik harus berpedoman pada Standar Akuntansi Pemerintah (SAP) yang diatur dalam peraturan pemerintah No 71 Tahun 2010. Hasil penelitian yang dilakukan oleh Hidayattullah \& Herdjiono (2015) dan penelitian yang dilakukan oleh Zakiyudin \& Suyanto (2015) mengungkapkan bahwa sistem pelaporan berpengaruh positif terhadap akuntabilitas kinerja instansi pemerintahan. Penelitian ini sejalan dengan yang diungkapkan oleh Judarmita \& Supadmi (2017) mengungkapkan bahwa sistem pelaporan berpengaruh positif pada akuntabilitas.

$\mathrm{H}_{2}$ : Sistem pelaporan berpengaruh positif pada akuntabilitas pengelolaan dana desa di Kota Denpasar.

Pengaruh kompetensi perangkat desa pada pengelolaan dana desa berkaitan dengan teori keagenan. Permasalahan tersebut biasanya terjadi karena adanya kepentingan pribadi yang akan membawa dampak negatif bagi masyarakat. Teori keagenan menurut Jensen \& Meckling (1976) menggambarkan hubungan antara prinsipal dengan agen yang diberikan kepercayaan dalam mengelola dan mengambil keputusan atas nama prinsipal. Teori keagenan diharapkan meminimalisir konflik kepentingan yang terjadi dalam pengelolaan dana desa. Dalam pengelolaan dana desa yang terjadi antara prinsipal dan agen yang mana dalam hal ini pemerintah desa selaku pengelola dan masyarakat sebagai subjek pembangunan. Orang yang memiliki kompetensi diharapkan memiliki kinerja yang baik untuk mewujudkan tujuan organisasi (Hariyani \& Sudrajat, 2017). Penelitian terdahulu tentang kompetensi yang dilakukan oleh Mada et al., (2017) dan Sugiarti \& Yudianto (2017) memberikan kesimpulan yang sama yaitu kompetensi berpengaruh positif terhadap akuntabilitas pengelolaan dana desa.

$\mathrm{H}_{3}$ : Kompetensi perangkat desa berpengaruh positif pada akuntabilitas pengelolaan dana desa

\section{METODE PENELITIAN}

Penelitian ini dilakukan dengan menggunakan pendekatan kuantitatif yang berbentuk penelitian asosiatif. Penelitian dilakukan di 27 desa di Kota Denpasar. Variable dependen dalam penelitian ini adalah akuntabilitas pengelolaan dana desa (Y). Variabel independen dalam penelitian ini adalah kejelasan sasaran anggaran $\left(X_{1}\right)$, sistem pelaporan $\left(X_{2}\right)$, kompetensi perangkat desa $\left(X_{3}\right)$. Populasi dalam penelitian ini adalah perangkat desa di seluruh desa di Kota Denpasar dan sampel dalam penelitian ini sebanyak 135 orang yang ditentukan dengan metode non probability sampling yaitu Teknik purposive sampling, dengan kriteria merupakan perangkat desa yang terdiri atas Kepala desa, sekretaris desa, kepala urusan keuangan, kepala urusan perencanaan, Ketua BPD. Metode pengumpulan data dengan menggunakan kuesioner yang terdiri atas 4 pilihan jawaban, yaitu poin 4 Sangat Setuju (SS), poin 3 Setuju (S), poin 2 Tidak Setuju (TS), dan poin 3 Sangat Tidak Setuju (STS). Teknik analisi data yang digunakan dalam penelitian ini adalah analisis regresi linear berganda dengan tahapan (1) uji statistic deskripstif, (2) uji asumsi klasik, (3) analisi regresi linear berganda, (4) 
pengujian hipotesis meliputi uji koefisien determinasi $\left(\mathrm{R}^{2}\right)$, uji kelayakan model (Uji F), dan uji hipotesis (Uji t). Model regresi berganda dirumuskan dalam bentuk sebagai berikut.

$Y=\alpha+\beta_{1} X_{1}+\beta_{2} X_{2}+\beta_{3} X_{3}+\varepsilon$

Keterangan :

$\mathrm{Y}=$ Akuntabilitas Pengelolaan Dana Desa

$\alpha=$ Konstanta

$\beta_{1}=$ Koefisien regresi variabel kejelasan sasaran anggaran

$\beta_{2}=$ Koefisien regresi variabel sistem perencanaan

$\beta_{3}=$ Koefisien regresi variabel kompetensi perangkat desa

$\mathrm{X}_{1}=$ Kejelasan sasaran anggaran

$\mathrm{X}_{2}=$ Sistem pelaporan

$\mathrm{X}_{3}=$ Kompeetensi perangkat desa

$\varepsilon=$ Error

\section{HASIL DAN PEMBAHASAN}

Responden dalam penelitian ini sebanyak 135 orang. Kuesioner penelitian disebarkan ke 27 Desa yang ada Di Kota Denpasar, responden dalam penelitian ini merupakan penyelenggara pemerintahan desa di Kota Denpasar yang diantaranya terdiri dari kepala desa, sekretaris desa, kepala urusan keuangan, kepala urusan perencanaan, dan ketua BPD. Ringkasan pengembalian disajikan dalam Tabel 1.

Tabel 1. Rincian Pengiriman dan Pengembalian Kuesioner

\begin{tabular}{lc}
\hline \multicolumn{1}{c}{ Keterangan } & Jumlah \\
\hline Kuesioner yang disebar & 135 \\
Kuesioner yang tidak Kembali & 10 \\
Kuesioner yang dikembalikan & 125 \\
Kuesioner yang digunakan & 125 \\
Tingkat Pengembalian (Respons rate) & \\
Kuesioner yang dikembalikan $\times 100 \%$ & $92,6 \%$ \\
Kuesioner yang dikirim & \\
Tingkat Pengembalian yang digunakan (useable response rate) & $92,6 \%$ \\
Kuesioner yang diolah $\times 100 \%$ & \\
\hline Kuesioner yang dikirm
\end{tabular}

Sumber: Data Penelitian, 2020

Berdasarkan Tabel 1, menunjukkan bahwa kuesioner yang disebar sebanyak 135 kuesioner yang disebar ke 27 Desa Di Kota Denpasar dengan jumlah sampel 5 orang di setiap desa. Kuesioner yang kembali sebanyak 125 kuesioner. Sebanyak 10 kuesioner tidak kembali dikarenakan hilang dan kuesioner yang digunakan sebanyak 125 kuesioner. Kuesioner yang diolah sebanyak 125 kuesioner dengan persentase sebanyak $92,6 \%$.

Uji validitas dilakukan untuk mengukur sah atau tidak sahnya suatu kuesioner. Uji validitas dilakukan dengan menghitung nilai korelasi antara skor masing-masing pertanyaan atau pernyataan dengan nilai skor total sehingga didapatkan nilai Pearson Corelation menyatan bahwa bila korelasi tiap faktor tersebut bernilai positif dan lebih besar dari 0,3 hal tersebut menunjukkan seluruh indikator yang terdapat pada penelitian ini terbukti valid (Sugiyono, 2017:125). 
Tabel 2. Hasil Uji Validitas

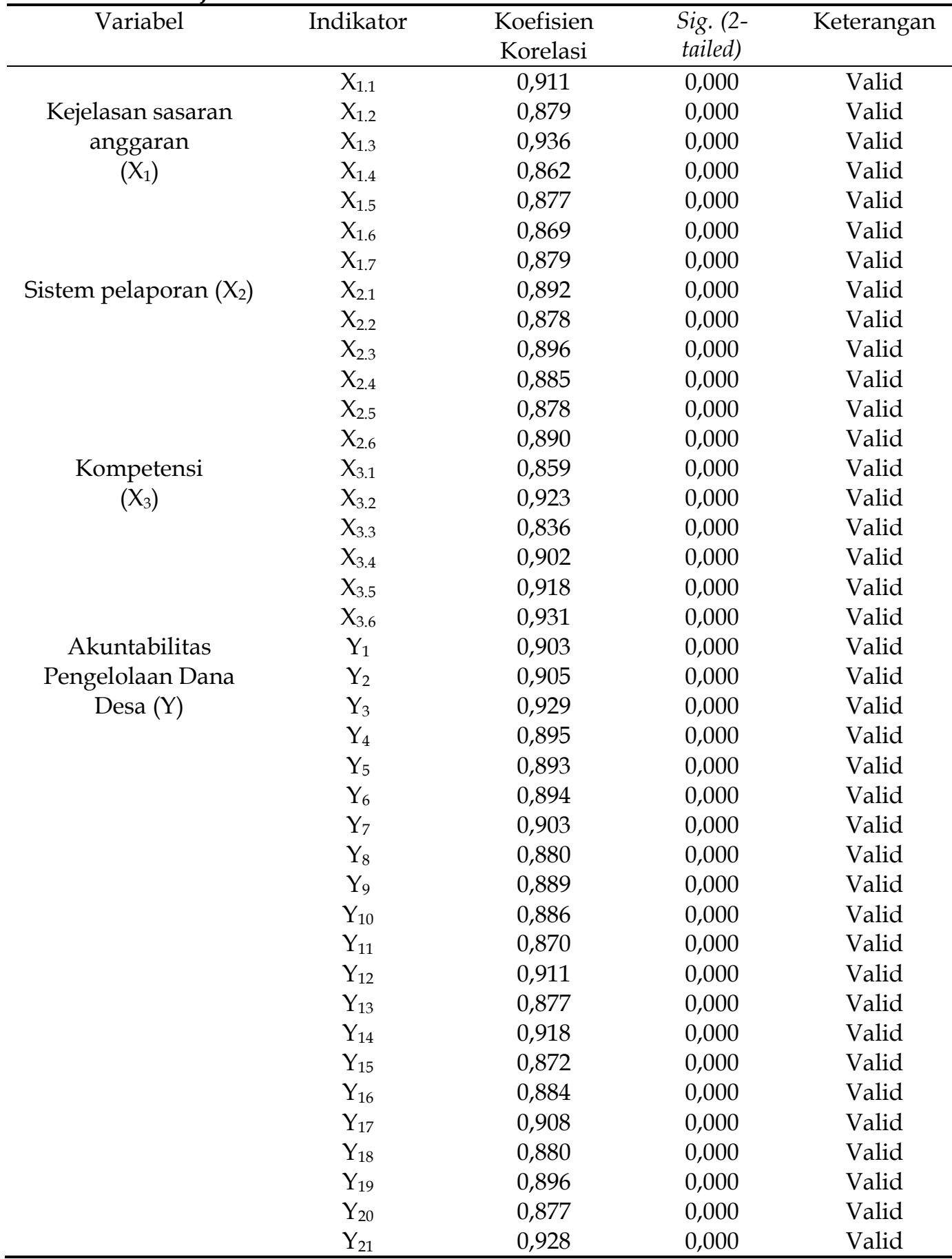

Sumber: Data Penelitian, 2020

Hasil uji validitas pada Tabel 2, menunjukkan bahwa seluruh instrumen penelitian yang digunakan untuk mengukur variabel kejelasan sasaran anggaran, sistem pelaporan, kompetensi perangkat desa dan akuntabilitas pengelolaan dana desa memiliki nilai koefisien korelasi dengan skor total seluruh item pernyataan lebih besar dari 0,3 dengan signifikansi kurang dari 0,05 . Hal ini menunjukkan bahwa butir-butir pernyataan dalam instrument 
penelitian tersebut valid dan layak digunakan sebagai instrument penelitian. Uji reliabilitas data dalam penelitian ini dilakukan dengan melihat nilai Cronbach's Alpha. Jika nilai Cronbach's Alpha lebih besar dari 0,60 maka butir pertanyaan atau pernyataan pada masing-masing variabel penelitian tersebut dinyatakan reliabel.

Uji reliabilitas dilakukan untuk mengukur handal atau tidaknya kuesioner yang digunakan untuk mengukur variabel penelitian. Suatu koesioner dikatakan reliabel atau handal jika jawaban responden terhadap pernyataan adalah konsisten dari waktu ke waktu (Sugiyono, 2017:130).

Tabel 3. Hasil Uji Reliabilitas

\begin{tabular}{clcc}
\hline No. & \multicolumn{1}{c}{ Variabel } & Cronbach's Alpha & Keterangan \\
\hline 1 & Kejelasan sasaran anggaran $\left(\mathrm{X}_{1}\right)$ & 0,950 & Reliabel \\
2 & Sistem pelaporan $\left(\mathrm{X}_{2}\right)$ & 0,946 & Reliabel \\
3 & Kompetensi $\left(\mathrm{X}_{3}\right)$ & 0,949 & Reliabel \\
4 & Akuntabilitas Pengelolaan Dana & 0,987 & Reliabel \\
& Desa $(\mathrm{Y})$ & & \\
\hline
\end{tabular}

Sumber: Data Penelitian, 2020

Hasil uji reliabilitas yang disajikan dalam Tabel 3, menunjukkan bahwa seluruh instrumen penelitian yaitu kejelasan sasaran anggaran, sistem pelaporan, kompetensi perangkat desa dan akuntabilitas pengelolaan dana desa memiliki koefisien Cronbach's Alpha lebih dari 0,60. Jadi dapat dinyatakan bahwa seluruh variabel telah memenuhi syarat reliabilitas atau kehandalan sehingga dapat digunakan untuk melakukan penelitian.

Statistik deskriptif adalah ststistik yang digunakan untuk menganalisis data dengan cara mendeskripsikan atau menggambarkan data yang telah terkumpul sebagaimana adanya tanpa bermaksud membuat kesimpulan yang berlaku umum atau generalisasi (Sugiyono, 2017:79).

Tabel 4. Hasil Uji Deskriptif

\begin{tabular}{lccccc}
\hline \multicolumn{1}{c}{ Keterangan } & N & Minimum & Maximum & Mean & $\begin{array}{c}\text { Std. } \\
\text { Deviation }\end{array}$ \\
\hline Kejelasan sasaran & 125 & 10 & 28 & 23.09 & 4.540 \\
anggaran & 125 & 9 & 24 & 19.30 & 4.201 \\
Sistem pelaporan & 125 & 9 & 24 & 19.42 & 4.030 \\
Kompetensi & 125 & 30 & 84 & 67.66 & 14.463 \\
$\begin{array}{l}\text { Akuntabilitas } \\
\text { Pengelolaan Dana Desa }\end{array}$ & 125 & & & & \\
Valid N (listwise) & & & &
\end{tabular}

Sumber: Data Penelitian, 2020

Variabel kejelasan sasaran anggaran memiliki $\mathrm{N}$ sebesar 125, nilai minimum sebesar 10 dan nilai maksimum sebesar 28, rata-rata sebesar 23,09 dengan nilai standar deviasi sebesar 4,540. Variabel sistem pelaporan memiliki $\mathrm{N}$ sebesar 125, nilai minimum sebesar 9 dan nilai maksimum sebesar 24, rata-rata sebesar 19,30 dan nilai standar deviasi sebesar 4,201. Variabel kompetensi perangkat desa memiliki $\mathrm{N}$ sebesar 125, nilai minimum sebesar 9 dan nilai maksimum sebesar 24, rata-rata sebesar 19,42 dan nilai standar deviasi sebesar 4,030. Variabel akuntabilitas pengelolaan dana desa memiliki $\mathrm{N}$ sebesar 125 , nilai minimum sebesar 30 dan nilai maksimum sebesar 84, rata-rata sebesar 67,66 dan nilai standar deviasi sebesar 14,463. Dapat disimpulkan bahwa jawaban 
responden tentang kejelasan sasaran anggaran, sistem pelaporan, kompetensi perangkat desa dan akuntabilitas pengelolaan dana desa sudah merata.

Uji normalitas bertujuan untuk menguji apakah dalam model regresi, variabel residual mempunyai distribusi data normal atau mendekati normal. Normalitas data dapat diketahui dengan membandingkan antara tingkat signifikansi yang didapat dengan tingkat alpha yang digunakan, dimana data tersebut dikatakan berdistribusi normal apabila nilai Asymp.sig. (2-tailed) lebih besar dari $a=0,05$ (Ghozali, 2016:30).

\section{Tabel 5. Hasil Uji Normalitas}

\begin{tabular}{cc}
\hline & Unstandardized Residual \\
\hline $\mathrm{N}$ & 125 \\
Kolmogorov-Smirnov Z & 0,838 \\
Asymp.Sig.(2-tailed) & 0,484 \\
\hline
\end{tabular}

Sumber: Data Penelitian, 2020

Hasil uji normalitas pada Tabel 5, menunjukan bahwa besarnya nilai Asymp. Sig. (2-tailed) adalah sebesar 0,484 yang lebih besar dari 0,05. Berdasarkan hasil tersebut dapat dikatakan bahwa data terdistribusi secara normal, sehingga dapat disimpulkan bahwa model memenuhi asumsi normalitas.

Uji multikolinieritas dimaksudkan untuk membuktikan atau menguji ada atau tidaknya hubungan yang linier (multikolinieritas) antara variabel bebas (independen) satu dengan variabel bebas yang lain. Adanya multikolinieritas dapat dilihat dari nilai tolerance dan nilai variance inflation factor (VIF). Nilai tolerance rendah sama dengan nilai VIF tinggi karena VIF $=1$ tolerance. Dengan kata lain tidak terjadi multikolinieritas adalah yang memiliki nilai VIF $<10$ dan memiliki angka tolerance $>0,1$.

\section{Tabel 6. Hasil Uji Multikoleniaritas}

\begin{tabular}{lccc}
\hline \multicolumn{1}{c}{ Variabel } & Tolerance & VIF & Keterangan \\
\hline Kejelasan sasaran anggaran $\left(\mathrm{X}_{1}\right)$ & 0,627 & 1,595 & Bebas multikol \\
Sistem pelaporan $\left(\mathrm{X}_{2}\right)$ & 0,549 & 1,820 & Bebas multikol \\
Kompetensi $\left(\mathrm{X}_{3}\right)$ & 0,554 & 1,805 & Bebas multikol \\
\hline
\end{tabular}

Sumber: Data Penelitian, 2020

Hasil uji multikoleniaritas pada Tabel 6, dapat dilihat bahwa nilai tolerance dan VIF dari seluruh variable tersebut menunjukkan bahwa nilai tolerance untuk setiap variabel lebih besar dari $10 \%$ atau 0,1 dan nilai VIF lebih kecil dari 10 yang berarti model persamaan regresi bebas dari multikolinearitas.

Uji heteroskedastisitas adalah suatu pengujian untuk mengetahui apakah variabel yang dioperasikan telah mempunyai varian yang sama atau tidak. Jika tidak mengandung heteroskedastisitas, nilai signifikan variabel bebas terhadap nilai absolute residual lebih besar dari $\alpha=0,05$ (Ghozali, 2016:31)

\section{Tabel 7. Hasil Uji Heteroskedastisitas}

\begin{tabular}{lcc}
\hline \multicolumn{1}{c}{ Variabel } & Signifikansi & Keterangan \\
\hline Kejelasan sasaran anggaran $\left(\mathrm{X}_{1}\right)$ & 0,507 & Bebas heteroskedastisitas \\
Sistem pelaporan $\left(\mathrm{X}_{2}\right)$ & 0,739 & Bebas heteroskedastisitas \\
Kompetensi $\left(\mathrm{X}_{3}\right)$ & 0,688 & Bebas heteroskedastisitas \\
\hline
\end{tabular}


Tabel 7, menunjukkan bahwa nilai signifikansi dari masing-masing variabel adalah di atas 0,05 . Hal ini menunjukkan bahwa seluruh variabel tersebut bebas dari heteroskedastisitas.

Analisis Regresi Linier Berganda diolah dengan bantuan software SPSS for Windows dengan hasil yang dapat dilihat pada tabel 8 .

Tabel 8. Hasil Analisis Regresi Linier Berganda

\begin{tabular}{lccccc}
\hline \multirow{2}{*}{ Model } & \multicolumn{2}{c}{$\begin{array}{c}\text { Unstandardized } \\
\text { Coefficients }\end{array}$} & $\begin{array}{c}\text { Standardized } \\
\text { Coefficients }\end{array}$ & & \\
\cline { 2 - 4 } & $\mathrm{B}$ & Std. Error & Beta & $\mathrm{T}$ & Sig. \\
\hline 1 (Constant) & 0,735 & 4,299 & & 171 & 0,864 \\
Kejelasan sasaran anggaran & 0,771 & 0,205 & 0,242 & 3,767 & 0,000 \\
Sistem pelaporan & 1,576 & 0,236 & 0,458 & 6,664 & 0,000 \\
Kompetensi & 0,963 & 0,245 & 0,268 & 3,926 & 0,000 \\
R & 0,829 & & & & \\
R Square & 0,686 & & & & \\
Adjusted R Square & 0,679 & & & & \\
$\quad$ F Statistik & 88,316 & & & & \\
Signifikansi Uji F & 0,000 & & & & \\
\hline
\end{tabular}

Sumber: Data Penelitian, 2020

Berdasarkan Tabel 8, dapat disusun persamaan regresi sebagai berikut.

$$
\mathrm{Y}=0,735+0,771 \mathrm{X}_{1}+1,576 \mathrm{X}_{2}+0,963 \mathrm{X}_{3}
$$

Hasil persamaan regresi linier berganda menunjukan besar dan arah pengaruh masing-masing variabel bebas pada variabel terikatnya. Koefisien regresi yang memiliki nilai positif berarti memiliki pengaruh yang searah. Nilai koefisien regresi dari kejelasan sasaran anggaran $\left(X_{1}\right)$, sebesar 0,771 menunjukan bahwa terdapat pengaruh positif antara variabel kejelasan sasaran anggaran terhadap pemilihan akuntabilitas pengelolaan dana desa sebesar 0,771. Hal ini berarti apabila variabel independen kejelasan sasaran anggaran meningkat sebesar 1 satuan dengan asumsi bahwa variabel bebas lainnya konstan, maka variabel akuntabilitas pengelolaan dana desa akan mengalami peningkatan sebesar 0,771. Nilai koefisien regresi dari sistem pelaporan $\left(X_{2}\right)$, sebesar 1,576 menunjukan bahwa terdapat pengaruh positif antara variabel sistem pelaporan terhadap akuntabilitas pengelolaan dana desa sebesar 1,576. Hal ini berarti apabila variabel independen sistem pelaporan meningkat sebesar 1 satuan dengan asumsi bahwa variabel bebas lainnya konstan, maka variabel akuntabilitas pengelolaan dana desa akan mengalami peningkatan sebesar 1,576. Nilai koefisien regresi dari kompetensi perangkat desa $\left(X_{3}\right)$, sebesar 0,963 menunjukan bahwa terdapat pengaruh positif antara variabel kompetensi perangkat desa terhadap akuntabilitas pengelolaan dana desa sebesar 0,963. Hal ini berarti apabila variabel independen kompetensi meningkat sebesar 1 satuan dengan asumsi bahwa variabel bebas lainnya konstan, maka variabel akuntabilitas pengelolaan dana desa akan mengalami peningkatan sebesar 0,963.

Koefisien determinasi $\left(\mathrm{R}^{2}\right)$ digunakan untuk mengetahui dan mengukur kemampuan model dalam menerangkan variasi variabel independen. Berdasarkan Tabel 8, nilai Adjust $R$ Square sebesar 0,679, hal ini berarti 67,9 persen variansi Akuntabilitas Pengelolaan Dana Desa dipengaruhi oleh variansi Kejelasan Sasaran Anggaran $\left(X_{1}\right)$, Sistem Pelaporan $\left(X_{2}\right)$ dan Kompetensi Perangkat Desa $\left(X_{3}\right)$, sisanya dipengaruhi oleh faktor lain di luar model. 
Hasil uji $\mathrm{F}$ yang di analisis dengan menggunakan program SPSS

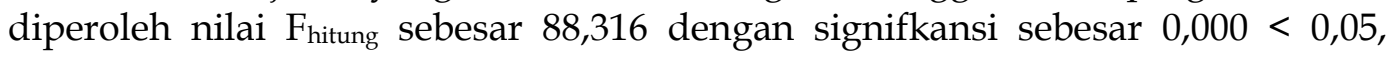
maka dapat disimpulkan bahwa pada kelompok yang diuji memiliki perbedaan yang nyata (signifikan). Hasil ini mempunyai arti bahwa ada pengaruh signifikan antara kejelasan sasaran anggaran, sistem pelaporan dan kompetensi perangkat desa terhadap akuntabilitas pengelolaan dana desa.

Uji $\mathrm{t}$ atau uji hipotesis dilakukan dilakukan untuk mengetahui pengaruh kejelasan sasaran anggaran, sistem pelaporan, kompetensi perangkat desa pada akuntabilitas pengelolaan dana desa. Hasil analisis variabel kejelasan sasaran anggaran pada akuntabilitas pengelolaan dana desa diperoleh nilai koefisien regresi yang bernilai positif sebesar 0,771 dan nilai signifikasi sebesar $0,000<$ 0,050 mengindikasikan bahwa $\mathrm{H}_{1}$ diterima. Hasil ini mempunyai arti bahwa kejelasan sasaran anggaran berpengaruh positif dan signifikan pada akuntabilitas pengelolaan dana desa. Hal ini berarti bahwa semakin baik kejelasan sasaran anggaran maka akan menyebabkan meningkatnya akuntabilitas pengelolaan dana desa. Teori agensi menjelaskan akuntabilitas merupakan kewajiban pemegang amanah dalam hal ini kepala desa dan aparatur desa untuk memberikan pertanggungjawaban, menyajikan, melaporkan, dan mengungkapkan segala aktivitas dan kegiatan yang dilakukan dengan menggunakan dana desa kepada pihak masyarakat sebagai prinsipal. Dengan sasaran anggaran yang jelas maka akan mempermudah pemerintah desa untuk mempertanggungjawabkan penggunaan dana sehingga mendoring terjadinya akuntabilitas pengelolaan dana desa. Hasil ini mendukung penelitian yang dilakukan oleh Amalia (2017) dan Nursalam (2016) menyimpulkan bahwa kejelasan sasaran anggaran berpengaruh positif pada akuntabilitas.

Berdasarkan hasil pengujian (uji t) dalam penelitian ini, didapatkan hasil bahwa sistem pelaporan mempunyai nilai koefisien regresi positif sebesar 1,576 dan Sig t 0,000<0,050. Hasil pengujian tersebut menunjukkan bahwa hipotesis kedua $\left(\mathrm{H}_{2}\right)$ sistem pelaporan mempunyai pengaruh yang positif terhadap akuntabilitas pengelolaan dana desa diterima. Teori agensi menjelaskan tentang pentingnya sistem pelaporan dalam menjaga kepercayaan yang diberikan oleh pemerintah pusat dan masyarakat kepada pemerintah desa dalam mengelola keuangan desa. Kepala desa dan perangkat desa harus melaporkan pengelolaan dana desa serta kebijakan yang ditetapkan dalam pengelolaan dana desa kepada masyarakat. Hasil ini mendukung penelitian yang dilakukan oleh Judarmita \& Supadmi (2017) yang mengungkapkan bahwa sistem pelaporan berpengaruh positif pada akuntabilitas pengelolaan dana desa.

Berdasarkan hasil pengujian (uji t) dalam penelitian ini, didapatkan hasil bahwa kompetensi mempunyai nilai koefisien regresi positif sebesar 0,963 dan Sig t 0,000<0,050. Hasil pengujian tersebut menunjukkan bahwa hipotesis ketiga $\left(\mathrm{H}_{3}\right)$ kompetensi mempunyai pengaruh yang positif pada akuntabilitas pengelolaan dana desa diterima. Dalam pengelolaan dana desa yang terjadi antara prinsipal dan agen yang mana dalam hal ini pemerintah desa selaku pengelola dan masyarakat sebagai subjek pembangunan. Kepatuhan seseorang akan norma dan aturan dapat menjadi cerminan tingkat kompetensi yang dimilikinya. Hasil ini mendukung penelitian yang dilakukan oleh Mada et al., 
(2017) dan Sugiarti \& Yudianto (2017) memberikan kesimpulan yang sama yaitu kompetensi berpengaruh positif terhadap akuntabilitas pengelolaan dana desa.

\section{SIMPULAN}

Kejelasan sasaran anggaran, sistem pelaporan dan kompetensi perangkat desa memiliki pengeruh positif pada akuntabilitas pengelolaan dana desa. Hal ini menunjukkan bahwa semakin tinggi kejelasan sasaran anggaran, sistem pelaporan dan kompetensi perangkat desa maka akuntabilitas pengelolaan dana desa semakin tinggi. Perangkat desa harus meningkatkan kompetensi yang dimiliki melalui pelatihan, bimbingan, penguasaan teknologi informasi untuk dapat mengelola keuangan dana desa dengan baik. Pemerintah Kota Denpasar perlu melakukan pengawasan dan pemeriksaan yang dilakukan secara berkala oleh inspektorat sehingga tercipta pengelolaan dana desa yang akuntabel.

\section{REFERENSI}

Adhayanto, O., Arianto, B., Winatawira, W., Suryadi, S., \& Nurhasanah, N. (2019). The Evaluation of the Utilization of the 2018 Village Funds in Bintan District and Lingga District. Jurnal Bina Praja, 2(21), 125-136. https://doi.org/10.21787/jbp.11.2019.125-136

Afiah, N. N., \& Azwari, P. C. (2015). The Effect of the Implementation of Government Internal Control System (GICS) on the Quality of Financial Reporting of the Local Government and its Impact on the Principles of Good Governance: A Research in District, City, and Provincial Government in Sou. Procedia - Social and Behavioral Sciences, 211, 811-818. https://doi.org/10.1016/j.sbspro.2015.11.172

Afrida, R. (2017). Pengaruh Kejelasan Sasaran Anggaran, Budaya Organisasi, Kualitas Sistem Pelaporan Terhadap Pengukuran Kinerja Instansi Pemerintah Daerah. Jurnal Universitas Negeri Padang, 3, 1-28. https://doi.org/10.1017/CBO9781107415324.004

Amalia, S. H. (2017). Pengaruh Kejelasan Sasaran Anggaran, Pengendalian Akuntansi, Dan Sistem Pelaporan Terhadap Akuntabilitas Kinerja Instansi Pemerintah Di Kabupaten Musi Banyuasin. Journal of Chemical Information and Modeling, 53(9), 1689-1699. https:/ / doi.org/10.1017/CBO9781107415324.004

Arta, I. M. A. S., \& Rasmini, N. K. (2019). Pengaruh Kejelasan Sasaran Anggaran, Sistem Pelaporan dan Partisipasi Masyarakat Pada Akuntabilitas Pengelolaan Dana Desa. E-Jurnal Akuntansi, 26(1), 709-735. https://doi.org/10.24843/ eja.2019.v26.i01.p26

Ash-shidiqqi, E. A., \& Wibisono, H. (2018). Corruption and Village: Accountability of Village Fund Management on Preventing Corruption (Problems and Challenges). Journal of Indonesian Legal Studies, 3(02), 195-212. https://doi.org/10.15294/jils.v3i02.27524

Atmadja, A. T., Saputra, K. A. K., \& Koswara, M. K. (2018). The influence of village conflict, village apparatus ability, village facilitator competency and commitment of local government on the success of budget management. Academy of Accounting and Financial Studies Journal.

Aulia, P., Agusti, R., \& Julita. (2018). Pengaruh Kompetensi Aparat Pengelola 
Dana Desa, Komitmen Organisasi Pemerintah Desa, Pemanfaatan Teknologi Informasi, dan Partisipasi Masyarakat terhadap Akuntabilitas Pengelolaan Dana Desa di Kabupaten 50 Kota. Jurnal Online Mahasiswa Fakultas Ekonomi Universitas Riau, 1(1), 1-15.

Aziz, A. (2016). Pengaruh Karakteristik Pemerintah Daerah Terhadap Kinerja Keuangan Pemerintah Daerah Kabupaten \& Kota Di Jawa Timur. EKSIS, 11(1), 86-101. https://doi.org/10.25273/jap.v7i1.1823

Azlina, N., Hasan, A., Desmiyawati, \& Muda, I. (2017). The effectiveness of village fund management (case study at villages in coastal areas in Riau). International Journal of Economic Research.

Boučková, M. (2015). Management Accounting and Agency Theory. Procedia Economics and Finance, 25(15), 5-13. https://doi.org/10.1016/s22125671(15)00707-8

Dewi, N. F., Azam, S. . F., \& Yusoff, S. K. M. (2019). Factors Influencing the Information Quality of Local Government Financial Statement And Financial Accountability. Management Science Letters, 9(9), 1373-1384. https://doi.org/10.5267/j.msl.2019.5.013

Efrizar, R., Hardi, \& Wiguna, M. (2017). Pengaruh Kejelasan Sasaran Anggaran, Akuntabilitas Publik, dan Sistem Pelaporan Terhadap kinerja Manajerial (Studi Empiris Pada SKPD Kabupaten Rokan Hulu). Jom Fekon, 4(1), 17261740.

Fitriyani, L. Y., Marita, Widyastuti, \& Nurahman, R. W. (2018). Determinants of Village Fund Allocation. Jurnal Akuntansi Multiparadigma, 9(3), 526-539. https://doi.org/10.18202/jamal.2018.04.9031

Ghozali, I. (2016). Statistik Non-Parametrik: Teori dan Aplikasi dengan Program SPSS. In Universitas Diponegoro. Semarang. https://doi.org/10.1002/14651858.CD002812

Glinkowska, B., \& Kaczmarek, B. (2016). Classical And Modern Concepts of Corporate Governance (Stewardship Theory and Agency Theory). Management, 19(2), 84-92. https:// doi.org/10.1515/manment-2015-0015

Hariyani, D. S., \& Sudrajat, M. A. (2017). Analisis Pengaruh Kompetensi Aparatur Pemerintahan Desa Terhadap Penggunaan Teknologi Accounting Information System Pada Desa-Desa Di Kabupaten Madiun. Assets: Jurnal Akuntansi Dan Pendidikan, 5(2), 113-128. https://doi.org/10.25273/jap.v5i2.1193

Hidayattullah, A., \& Herdjiono, I. (2015). Pengaruh Kejelasan Sasaran Anggaran, Pengendalian Akuntansi, Sistem Pelaporan Terhadap Akuntabilitas Kinerja SKPD Di Merauke. Prosiding Seminar Nasional Multi Disiplin Ilmu \& Call for Papers Unisbank (Sendi_U), 978-979.

Jensen, M. C., \& Meckling, W. H. (21976). Theory of the Firm : Magerial Behavior, Agency Cost and Ownership Structure. Journal of Financial Economics, 5(4), 305-360.

Judarmita, I. N., \& Supadmi, N. L. (2017). Pengaruh Kejelasan Sasaran Anggaran, Sistem Pelaporan dan Audit Kinerja Terhadap Akuntabilitas Pengelolaan Dana Desa. E-Jurnal Akuntansi Universitas Udayana, 21(3), 1719-1746.

Mada, S., Kalangi, L., \& Gamaliel, H. (2017). Pengaruh Kompetensi Aparat Pengelola Dana Desa, Komitmen Organisasi Pemerintah Desa, dan 
Partisipasi Masyarakat Terhadap Akuntabilitas Pengelolaan Dana Desa Di Kabupaten Gorontalo. Jurnal Riset Akuntansi Dan Auditing "Goodwill," 8(2), 106-115. https://doi.org/10.35800/jjs.v8i2.17199

Meutia, I., \& Liliana, L. (2018). The Management of Village Fund Finances. Jurnal Dinamika Akuntansi, 9(1), 63-81. https://doi.org/10.15294/jda.v9i1.12009

Panjaitan, I., \& Shopiana, S. (2017). Pengaruh Karateristik Tujuan Anggaran Dan Penerapan Sistem Informasi Akuntansi Terhadap Kinerja Aparat Pemerintah Daerah Dengan Tingkat Desentralisasi Sebagai Pemoderasi. Jurnal Tata Kelola \& Akuntabilitas Keuangan Negara, 3(1), 33-48. https://doi.org/10.28986/jtaken.v3i1.69

Prasetya, I. K. Y. B., Prayudi, M. A., \& Diatmika, I. P. G. (2017). Pengaruh Kompetensi Sumber Daya, Pemahaman, dan Pengawasan Terhadap Kualitas Sistem Keuangan Desa di Kabupaten Buleleng. E-Journal S1 Ak Universitas Pendidikan Ganesha, 8(2), 1-11.

Precelina, D. D., \& Wuryani, E. (2019). Pengaruh Kejelasan Sasaran Anggaran, Pengendalian Akuntansi, dan Sistem Pelaporan Terhadap Akuntabilitas Kinerja Instansi Pemerintah Kabupaten Jombang. Jurnal Akuntansi AKUNESA, 7(3), 1-10.

Ruri, S. S. (2016). Pengaruh Kejelasan Sasaran Anggaran, Pengendalian Akuntansi dan Sistem Pelaporan Terhadap Akuntabilitas Kinerja Instansi Pemerintah (Studi pada Satuan Perangkat kerja Kabupaten Bengkalis). JOM FEKON, 3(1), 705-719. https:// doi.org/10.1017/CBO9781107415324.004

Santoso, E. B. (2016). Pengaruh Sistem pengendalian Intern Pemerintah, Pemanfaatan Teknologi Informasi dan Kompetensi Sumber Daya Manusia Terhadap Akuntabilitas Keuangan Daerah (Studi Empiris pada Pemerintah Kabupaten Lampung Timur). IOSR Journal of Economics and Finance, 3(1), 56. https://doi.org/https://doi.org/10.3929/ethz-b-000238666

Setyanto, E., \& Ritchi, H. (2018). Faktor-Faktor yang Mempengaruhi Akuntabilitas Keuangan Pemerintah Daerah. Jurnal Ilmiah Akuntansi, 9(1), 89-105.

Sugiarti, E., \& Yudianto, I. (2017). Analisis Faktor Kompetensi Sumber Daya Manusia , Pemanfaatan Teknologi Informasi , dan Partisipasi Penganggaran Terhadap Akuntabilitas Pengelolaan Dana Desa (Survei Pada Desa-Desa di Wilayah Kecamatan Klari, Kecamatan Karawang Timur, Kecamatan Majalaya. Proceedings, 580-590.

Sugiyono. (2017). Metode Penelitian Bisnis (Pendekatan Kuantitatif, Kualitatif, Kombinasi dan R\&D). In Metodelogi Penelitian.

Triyono, Achyani, F., \& Arfiansyah, M. A. (2019). The Determinant Accountability Of Village Funds Management (Study in the Villages in Wonogiri District). Riset Akuntansi Dan Keuangan Indonesia, 4 (Vol 4, No 2 (2019)), 118-135. https://doi.org/10.23917/reaksi.v4i2.8521

Zakiyudin, M. A., \& Suyanto. (2015). Kejelasan Sasaran Anggaran , Pengendalian Akuntansi , Sistem Pelaporan dan Akuntabilitas Kinerja Instansi Pemerintah Pada Inspektorat Jenderal Kementerian Agama RI. Jurnal Riset Akuntansi Dan Perpajakan JRAP, 2(1), 89-96. 